\title{
Bacteriological Quality of Soya Bean Cake (Awara) sold at Bayero University, Kano - Nigeria
}

\author{
M. Yusha'u, B. Atabor, D. W. Taura, L. Garba, I. Abdulrahman
}

\begin{abstract}
Soya bean cake (Awara) is a ready to eat food commonly sold and consumed by students in Nigerian schools including university campuses. A total of 20 samples of soya bean cake samples were purchased from different locations at Bayero University (old and new) campuses. The samples were blended, serially diluted and subjected to bacteriological analyses using; aerobic plate count, staphylococcal count and the most probable number technique for coliform detection. Discrete colonies were further subjected to Gram's staining and standard biochemical tests for identification. The results of aerobic mesophilic count showed that the samples contain counts ranging from $5.60 \times 10^{4}$ to $2.26 \mathrm{X}$ $10^{5} \mathrm{CFU} / \mathrm{g}$. The results of coliform count using the most probable number showed that the samples contain coliforms within the range of 10.5 to counts greater than 2400 per 100 grams of sample. Biochemical characterization of the isolates revealed the presence of Staphylococcyus aureus 17(85\%), Escherichia coli 16(80\%), Enterobacter aerogens 16(80\%), Shigella spp. 10(50\%), Salmonella spp. 9(45\%) and Vibrio spp. 7(35\%). The presence of a host of pathogenic bacteria in Awara samples examined poses a serious threat to consumers that can lead to outbreak of infections. This calls for the need to regulate the activities of Awara sellers on both campuses coupled with campaign for improved personal hygiene of the sellers so as to safe guard the health of both students and general public.
\end{abstract}

Keywords - Food, Bacteria, Soya bean cake, Count, MPN.

\section{INTRODUCTION}

FOODS are excellent sources of nutrients and hence excellent environments for the growth of microorganisms. Microbial growth is controlled by factors related to the food itself (intrinsic factors) and also to the environment where the food is being stored (extrinsic factors). Food composition is a critical intrinsic factor that influences microbial growth. If a food consists primarily of carbohydrates, spoilage does not result in major odours [1].

Soya bean is a rich source of protein and fat as well as vitamins and minerals hence it sometimes serve as meat substitute [11]. Soya bean cake (Awara) is a staple food of great nutritional value and pleasant taste commonly found in northern part of Nigeria. It is one of the delicacies particularly among females including students of higher institutions.

M. Yusha'u - Bayero University, Kano, Nigeria

B. Atabor - Bayero University, Kano, Nigeria

D. W. Taura - Bayero University, Kano, Nigeria

L. Garba - Gombe State University, Nigeria.

I. Abdulrahman - Kaduna State University, Nigeria
The presence of microorganisms in food has always been attributed to contamination through water, soil, processing equipment, contact surfaces and the food handlers [9]. Improper handling of food is responsible for most cases of food borne diseases and cross contamination [3].

This study is carried out to evaluate the bacteriological quality of soya bean cake through enumeration of aerobic mesophilic count, staphylococcus count and coliform.

This study was aimed at determining the bacteriological qulity of Awara sold within BUK campuses.

The objectives of the study include;

- Homogenizing the samples and serial te-fold dilution preparation.

- Enumerating aerobic mesophilic bacterial counts using pour plate method.

- Determining Staphylococcal counts using pour plate method.

- Enumerating coliforms using most probable number (MPN) technique.

- Isolation and identification of the isolates using standard biochemical procedures.

\section{MATERIALS AND METHODS}

\section{A. Sample Collection}

Duplicate samples were collected in sterile polythene bags directly from the sellers and immediately taken to the laboratory for analysis.

\section{B. Sample preparation and serial dilution}

This was carried out according to method described by Food and Agricultural Organization (FAO, 1979) and adopted by [10], twenty-five grams (25 g) of each sample was aseptically collected and placed in a sterile blender to which $225 \mathrm{ml}$ of buffered peptone water was added and homogenized for 2 min at normal speed. For the vegetables treated with salt, the vegetable sample in each of the solutions was allowed to stand for $10 \mathrm{~min}$ and thereafter homogenized and $1 \mathrm{ml}$ of the homogenate was 10 fold serially diluted. Serial dilution was carried out according to procedure described by [12].

Bacterial count (Aerobic plate Count and Staphylococcal count)

This was achieved using pour-plate method by pipetting $1 \mathrm{ml}$ of serially diluted sample into a sterile Petri plate followed by the addition of molten Baird Parker Agar (about $45^{\circ} \mathrm{C}$ ) and 
mixing well by gently swirling the plate on the bench top. The molten agar was allowed to solidify and the plates were then incubated at $37^{\circ} \mathrm{C}$ for 24 hours. Colonies on a plate (between 30-300) were counted and recorded [12].

\section{Coliform Count}

This was carried out according to the method described by [2]. In this method, a set up consisting of nine (9) test tubes each containing $9 \mathrm{ml}$ of lactose broth and inverted Durham tube, were autoclaved to expel air and to sterilize. Inoculation was made from the serially diluted samples from the $1: 10$ to 1:1000 dilutions. All the 9 test tubes were incubated at $37^{\circ} \mathrm{C}$ for 24 hours and another 24 hours in the absence of gas. Following 24 or 48 hours of incubation the tubes were observed for gas production and the number of gas positive tubes was compared with the most probable number (MPN) table to estimate the most probable number of coliforms per gram of the sample.

\section{Isolation and characterization of bacterial isolates}

Bacterial isolates were identied by their morphology on culture followed by biochemical characterization as described by [5].

\section{E. Isolation of Salmonella spp}

The homogenate was cultured onto Desoxycholate Citrate, MacConkey and Salmonella-Shigella agar followed by incubation at $37^{\circ} \mathrm{C}$ for 24 hours [7]. The colonies formed were Gram stained and tested for motility followed by biochemical tests [5].

\section{F. Isoation of Staphylococcus aureus}

Plates of Mannitol Salt Agar were inoculated with the homogenate and incubated at $35^{\circ} \mathrm{C}$ for 24 hour where $\mathrm{S}$. aureus produce yellow zones surrounding their growth [4]. The organism was confirmed biochemically by catalase and coagulase tests [5].

\section{G. Isolation of Vibrio spp}

This was achieved by culturing the homogenate in alkaline peptone water for 4hours followed by streaking on Thiosulphate Citrate Bile Salt agar and incubation incubation at $37^{\circ} \mathrm{C}$ for 24 hours. Yellow colonies indicating sucrose fermentation coupled with motility are exhibited by Vibrio specie which were followed by biochemical tests [5].

\section{H. Isolation of Shigella spp}

The homogenate was cultured onto Desoxycholate Citrate, MacConkey and Salmonella-Shigella agar followed by incubation at $37^{\circ} \mathrm{C}$ for 24 hours [7]. The colonies formed were Gram stained and tested for motility followed by biochemical tests [5].

\section{Gram's staining}

This was carried out as described by [5].

\section{J. Biochemical Tests for Identification of the Isolates}

The biochemical tests were carried out to confirm the identity of the organisms obtained based on standard protocols described by [5]. Thes include; Indole, Methyl-red, Citrate utilization, sugar fermentation (Tripple Sugar Iron), oxidase, Catalase and Coagulase tests.

\section{RESULTS}

The results of aerobic mesophilic bacterial count of the sample examined showed thatsite A had the highest count of 2.26 X 105 while site D had the least count of $5.69 \times 104$ (Table 1).

Analysis of Staphylococcal count indicated an overall mean count of 105 except for sites I and D with 1.74 X 104 and 0 counts (no growth) respectively as shown in table 2 .

Analysis of samples for total coliform showed that location $\mathrm{H}$ had the highest coliform count (>2400while location $\mathrm{G}$ had the least count of 10.5 (Table 3).

Tabe 4 shows the occurrence of bacterial species from the samples examined which indicated that $S$. aureus had the highest occurrence of $17(85 \%)$ while Vibrio spp. had the least occurrence of $7(35 \%)$.

Table 1: Aerobic Mesophilic Bacterial Counts Of Awara Samples

\begin{tabular}{llll}
\hline Site & Sample I & Sample II & Mean Count \\
\hline A & $2.45 \times 10^{5}$ & $2.07 \times 10^{5}$ & $2.26 \times 10^{5}$ \\
$\mathrm{~B}$ & $2.39 \times 10^{5}$ & $8.64 \times 10^{4}$ & $1.63 \times 10^{5}$ \\
$\mathrm{C}$ & $1.08 \times 10^{5}$ & $4.46 \times 10^{4}$ & $7.63 \times 10^{4}$ \\
$\mathrm{D}$ & $8.17 \times 10^{4}$ & $3.22 \times 10^{4}$ & $5.69 \times 10^{4}$ \\
$\mathrm{E}$ & $4.22 \times 10^{3}$ & $2.96 \times 10^{5}$ & $1.50 \times 10^{5}$ \\
$\mathrm{~F}$ & $1.68 \times 10^{5}$ & $6.69 \times 10^{4}$ & $1.17 \times 10^{5}$ \\
$\mathrm{G}$ & $3.01 \times 10^{4}$ & $8.70 \times 10^{4}$ & $5.86 \times 10^{4}$ \\
$\mathrm{H}$ & $1.29 \times 10^{5}$ & $2.29 \times 10^{5}$ & $1.79 \times 10^{5}$ \\
$\mathrm{I}$ & $1.21 \times 10^{5}$ & $1.65 \times 10^{5}$ & $1.43 \times 10^{5}$ \\
$\mathrm{~J}$ & $1.74 \times 10^{5}$ & $1.35 \times 10^{5}$ & $1.55 \times 10^{5}$ \\
\hline
\end{tabular}

TABLE II: STAPHYLOCOCCAL COUNTS OF AWARA SAMPLES

\begin{tabular}{llll}
\hline Site & Sample I & Sample II & Mean Count \\
\hline A & $3.57 \times 103$ & $3.12 \times 103$ & $3.35 \times 103$ \\
B & $2.97 \times 103$ & $3.01 \times 103$ & $2.99 \times 103$ \\
C & $1.87 \times 103$ & No growth & $9.35 \times 102$ \\
D & No growth & No growth & No growth \\
E & $2.41 \times 103$ & $5.35 \times 103$ & $3.88 \times 103$ \\
F & $3.02 \times 103$ & $1.55 \times 104$ & $9.26 \times 103$ \\
G & $2.92 \times 103$ & $3.77 \times 102$ & $1.65 \times 103$ \\
H & $3.54 \times 103$ & $5.51 \times 103$ & $4.54 \times 103$ \\
I & $3.66 \times 103$ & $3.12 \times 104$ & $1.74 \times 104$ \\
J & $1.61 \times 104$ & $2.61 \times 103$ & $9.36 \times 103$ \\
\hline
\end{tabular}

TABLE III: COLIFORM COUNTS OF AWARA SAMPLES

\begin{tabular}{llll}
\hline Isolates & $\begin{array}{l}\text { Number } \\
\text { positive }\end{array}$ & $\begin{array}{l}\text { Contamination } \\
(\%)\end{array}$ & rate \\
\hline $\begin{array}{l}\text { Enterobacter } \\
\text { aerogenes }\end{array}$ & 16 & 80 & \\
E. coli & & & \\
Salmonella spp & 9 & 80 \\
Shigella spp. & 10 & 50 \\
S. aureus & 17 & 85 \\
Vibrio spp. & 7 & 35 \\
\hline
\end{tabular}


TABLE 4: OCCURRENCE OF BACTERIAL ISOLATES IN AWARA SAMPLE

\begin{tabular}{llll}
\hline Site & Sample I & Sample II & $\begin{array}{l}\text { Mean } \\
\text { Count }\end{array}$ \\
\hline A & 1,100 & 150 & 625 \\
B & 1,100 & 120 & 610 \\
C & 150 & 75 & 112.5 \\
D & 150 & 21 & 85.5 \\
E & 11 & $>2400$ & 1205.5 \\
F & 1,100 & 120 & 610 \\
G & 14 & 7 & 10.5 \\
H & 150 & $>2400$ & 1275 \\
I & 120 & 150 & 135 \\
J & $>2400$ & 14 & 1207 \\
\hline
\end{tabular}

\section{DISCUSSION}

The overall results of this study indicated that samples A, B, E, F, H, I and J accounting for $70 \%$ of samples examined had mean aerobic mesophilic bacterial counts above the standard limit set by FAO (1979) i.e. $10^{5} \mathrm{CFU} / \mathrm{g}$. All samples had high MPN values indicating the occurrence of feacal coliforms that makes Awara a possible vehicle for food borne infections. This could be attributed to poor handling practices during production and at the point of sale because of frequent handling prior to buying. This predisposes consumers to the risk of infection by pathogenic bacteria.

The high occurrence (85\%) of S. aureus among the samples examined is an indication of frequent handling since the organism is a normal skin flora of humans. It is similar to the results observed by [6] and [8] where they isolated $S$. aureus from processed meat (Bulangu).

There exist very high rates of occurrences of E. coli $80 \%, E$. aerogenes $80 \%$, Shigella spp. 50\%, Salmonella spp. $45 \%$ and Vibrio spp. 35\% among the samples examined which may be due to the use of water contaminated with feacal matter in the preparation of the food, reduced personal hygiene and lack of good manufacturing practices among the sellers. This can result in the causation and spread of diseases such as urinary tract infections, gastroenteritis, peritonitis and enteric fevers. The result is similar to that observed by [14] where E. coli occurred at the rate of $60 \%$ in processed meat samples but different from that reported by [13] E. coli occurred at the rate of $27.7 \%$ in street vended foods.

\section{CONCLUSION}

The results of this study showed that the Awara samples examined were contaminated which render the food unsafe for human consumption.

In the light of the results observed in this study, it is recommended that;

The student union government should educate food handlers on good personal hygiene and good manufacturing practices.

The school management should regulate the activities of food sellers within the campuses so as to check the food quality and safety within the campuses.

\section{ACNOWLEDGMENT}

The authors wish to acknowledge the support of Bayero University Kano, Nigeria for financing this study.

\section{REFERENCES}

[1] Allen, J.C. and Hamilton, R.J. (1989). Rancidity in foods. Elsevier Applied Science, New York, NY, pp 78-79

[2] Atlas, R. M. (1997). Principles of Microbiology. $2^{\text {nd }}$ Edition. C. Brown publishers, USA. Pp.802-3.

[3] Bukar, A., Uba, A. and Oyeyi, T. I. (2009). Occurrence of enteropathogenic bacteria in some minimally and fully processed ready to eat foods in Kano metropolis. Nigeria Journal of Food Science 4(2): 32-36.

[4] Cappucino, J. G. and Sherman, N. (2002). Microbiology Laboratory Manual. 6the edition. Benjamin Cummings publishers, USA. Pp.1223.

[5] Cheesbrough, M. (2006). District Laboratory Practice in Tropical Countries (part 2) Second Edition; Cambridge University Press. Pp.35,64-70,157-8, 179-91. https://doi.org/10.1017/CBO9780511543470

[6] Chukwura, E. I. and Mojekwu, C. N. (2002). Communication: Prevalence of microbial contamination on Suya meat sold in Awka urban in metropolis. Journ. Trop. Microbiol. 1:89-91.

[7] Cloak, O. A., Duffy, G., Sheridan, J. J., McDowell, D. A. and Blair, I. S. (1999). Development of surface adhesion immunoflourescent Technique for the rapid Detection of salmonella spp. Ffrom meat and poultry. Journ. Of App. Microbiol. 86: 583-590. https://doi.org/10.1046/j.1365- 2672.1999.00698.x

[8] Jamila, S. D. (2005). Microbiological quality of roasted meat 'bulangu' in Kabuga road nearest to BUK gate. B. Sc. Thesis, Department of Biological Sciences, Bayero university, Kano.

[9] Kawo, A. H. and Abdulmumin, F. N. (2009). Microbiological quality and safety of pre-packaged sweets sold in metropolitan Kano, Nigeria. Bayero Journal of Pure and Applied Sciences 2(1): 154-159.

[10] Nwachukwu E. and Chukwu C. M. (2013) Effect of chemical treatments on the microbial load of fruits and vegetables. Applied Microbiology and Biotechnology Research, 1(2); 16-22

[11] Nwokolo, E. (1996). Soybean [Glycine max (L) Merr.] In: Legumes and oil seeds in Nutrition. Chapman Hull. Pp90-102.

[12] Madigan M. T., John M. M., Stahl D. A. and Clark D. P. (2012) Biology of Microoganisms; Thirteenth Edition; Pearson Press Inc., publishing. Pp 129-130

[13] Oyeyi, T. I. and Lum-Nwi, M. F (2008). Bacteriological quality of some street vended foods in Bayero University Campuses, Kano. Biol. Env. Journ. For the Trop. 5(4): 239-243.

[14] Shamsuddeen, U. and Yusha'u, M. (2006): Bacteriology of Meat sold at Kabuga, Kano. Biological and Environmental Sciences Journal for the Tropics 3(4): 95-98. 